\title{
Structural characteristics and mechanisms of fluorapatite mechanochemical synthesis
}

\author{
Vukoman Jokanović', Božana Čolović1, Marija Sandić-Živković2, Marijana Popović Bajić2, \\ Slavoljub Živković \\ "University of Belgrade, Institute of Nuclear Sciences "Vinca", Belgrade, Serbia; \\ 2University of Belgrade, Faculty of Dental Medicine, Belgrade, Serbia
}

\begin{abstract}
SUMMARY
This paper analyzes mechanisms of fluorapatite mechanochemical synthesis and its structural characteristics. Several studies of Jokanovic et al. published in appropriate journals and the book"Nanomedicine, the biggest challenge of the 21 st century" are the base for this article. Characteristics of obtained materials show numerous biological advantages associated with the specific structural design of material during the process of synthesis.

X-ray diffraction (XRD) and infrared spectroscopy with Fourier transform (FTIR) were used for studying the processes of fluorapatite synthesis.
\end{abstract}

Keywords: fluoroapatite; mechanochemical synthesis; X-ray diffraction; infrared spectroscopy; low-temperature treatment

\section{INTRODUCTION}

Fluorapatite (FA), chemical formula $\mathrm{Ca}_{5}\left(\mathrm{PO}_{4}\right)_{3} \mathrm{~F}$, or $\mathrm{Ca}_{10}\left(\mathrm{PO}_{4}\right)_{6} \mathrm{~F}_{2}$ is the most stable, least soluble, and the hardest calcium orthophos mineral (Mohs hardness scale 5). Such characteristics of fluoroapatite are associated to the specific position of $\mathrm{F}$ - ions in the center of the $\mathrm{Ca}_{2}$ triangle and its crystal structure. The synthesis techniques are similar to those of hydroxyapatite, but it should be noted that synthesis of fluoroapatite involves the presence of F- ions, which are transmitted into synthesis through $\mathrm{CaF}$, $\mathrm{NaF}$ or $\mathrm{NH}_{4} \mathrm{~F}$. Compared to hydroxyapatite (HA), which is Ca-deficient, there are no data to suggest $\mathrm{Ca}$-deficiency of fluoroapatite. The chemical formula of fluorapatite is $\mathrm{Ca}_{10}\left(\mathrm{PO}_{4}\right)_{6}(\mathrm{~F}, \mathrm{OH})_{2}$ as the most frequent modification of $\mathrm{OH}$-ions by F-ions is not complete. Among all human calcified tissues, the greatest concentration of fluorapatite is found in bones, and the lowest in enamel. However, even where there is the largest concentration of fluorapatite, the amount of fluoride is usually reduced related to stoichiometric quantities. Due to its low solubility (degradation rate), it is rarely used as a bone substitute.

Due to mechanical stability, its solubility is reduced and proliferation of bone tissue is improved. Hydroxyapatite / fluorapatite (FHA / FA) has been used as clinical restorative material in the recent years $[1,2]$. In addition, FHA and HA / FA, are used in biomedicine as carriers of drugs and catalysts or absorbents $[3,4]$.

Compared to HA [1], FHA / FA has better thermal and chemical stability $[5,6]$. When a certain number of $\mathrm{OH}$ groups in the HA matrix is replaced by F-ions, thermal and chemical stability of FHA / FA ceramics increases signifi- cantly. Theoretically, the ratio $\mathrm{F}: \mathrm{OH} \geq 1$ within the chain $\mathrm{OH}$ (in the FHA structure) would be sufficient to arrange HA crystals, stabilizing their structure due to alternating schedule of F-ions among $\mathrm{OH}$-ions.

In practice, materials that contain F-ions are widely used for dental restorations as they prevent tooth decay and reduce bacterial activity in an acidic environment. In addition, F-ions themselves favour mineralization and crystallization of calcium phosphate during bone formation [7]. Furthermore, in vitro studies FHA / FA have indicated its slow dissolution, better deposition layer as with hydroxyapatite, better adsorption of the protein [6-8], and similar or better cell attachment compared to pure HA [7, 9] as well as improved activity of alkaline phosphatase [6].

It has also ben shown that the presence of fluoride affects the increase in quantity and quality of bone in body [5]. Fluoride ion is used to treat osteoporosis because bone mass increases with the application of $\mathrm{F}^{-}$ions [9]. Fions also stimulate the activity of osteoblasts, both in vitro and in vivo. In addition, the mineral phase of enamel consists of HA (95 - 97\%) with from 0.04 to $0.07 \mathrm{wt}$. \% Fluoride. A dose of about 1.5-4 mg of fluoride per day significantly reduces the risk of tooth decay [5]. In addition to FHA and FHA phase, materials like $\mathrm{CaF}_{2}$ are also important in dentistry, because they can be used as reservoir of labile fluoride in caries prevention [10-14].

Some studies have shown that dual delivery system of (F-and $\mathrm{Ca}^{2+}$ ions) is necessary to allow homogeneous nucleation and formation of very small crystals of $\mathrm{CaF}_{2}$ in the mouth. These amounts are very efficient in increasing the deposition and retention of labile $\mathrm{F}^{-}$ions in the mouth, while at the same time remineralization effect increases 
without consequent increasing of F-content [15-23]. According to the research of Jokanovic et al. [24] it was described for the first time not only a specific method of synthesis of fluorapatite, but also a synthesis of combined system encapsulated in surface-active substance polyethylene vinyl acetate / versatate, which is a potential source of labile $\mathrm{CaF}_{2}$ phase. This is very important in order to maintain a balance of $\mathrm{F}$ ions content and to improve chemical and mechanical stability of the tooth.

For the synthesis of FHA / FA using precipitation, different methods are used like sol-gel, hydrolysis, hydrothermal method and solid phase reactions. They include appropriate ion exchange between the reactants that are used in the synthesis of FA [23-26]. Most chemical methods require very precise control of parameters of the synthesis process, product composition control and control of its characteristics, which is not so easy to achieve. Therefore, those methods are not suitable for the synthesis of FHA / FA on an industrial scale [27].

On the other hand, mechanochemical process is simple method that takes place in the solid state, allows synthesis of materials through the extremely efficient process of mixing different ion types due to shear forces, which using reduction of particle size and their alternating layers positioning improve thermodynamics and kinetic reactions between different solid substance precursors. In addition, compared to other above-mentioned processes, this method is more suitable regarding economic and technical sides because it enables mass production of nanocrystalline powders and high flexibility of process parameters [13].

The aim of this study was to present the method of synthesis of Nano powders fluorhydroxyapatite / fluorapatite using the method of mechanical alloying. Milling parameters such as speed of rotation, diameter, number of spheres, and weight ratio of the dust-spheres were constant, while the influence of milling time on phase composition was carefully defined. The kinetics and mechanism to obtain FHA / FA and other transitional phases were examined using XRD and FTIR spectroscopy.

\section{MECHANISMS OF FLUORAPATITE SYNTHESIS}

The mechanisms of fluorapatite synthesis are shown in the case of the most commonly used precursors such as calcium hydroxide $\mathrm{Ca}(\mathrm{OH})_{2}$, phosphorus pentoxide $\mathrm{P}_{2} \mathrm{O}_{5}$, and calcium fluoride $\mathrm{CaF}_{2}$ (synthesis 1 ) and calcium hydroxide $\mathrm{Ca}(\mathrm{OH})_{2}$, phosphorus pentoxide $\mathrm{P}_{2} \mathrm{O}_{5}$ and ammonium fluoride $\mathrm{NH}_{4} \mathrm{~F}$ with the addition of surface-active substance vinyl acetate / versatate (EVA / AVV) (synthesis 2). Both mechanisms are carried out through the series of processing steps that can be analyzed using IR spectroscopy and X-ray diffraction [24]. It was noted that each phase is followed by certain degree of transformation of starting reactants in fluorhydroxyapatite with smaller segments of $\mathrm{OH}^{-g}$ groups and larger segments of F-ions instead of $\mathrm{OH}$ groups, until complete transformation of fluorapatite is finished. Generally, the reaction is carried out with an incomplete stoichiometry where $\mathrm{x}$ is thevalue that defines deviation from complete symmetry and can be found in the interval $\mathrm{x}_{1}<\mathrm{x}<\mathrm{x}_{\mathrm{k}}$

$$
\begin{aligned}
& \mathrm{Ca}_{10}\left(\mathrm{PO}_{4}\right)_{1-\mathrm{y}}\left(\mathrm{CO}_{3}\right)_{\mathrm{y}}\left(\mathrm{PO}_{4}\right)_{5}(\mathrm{OH})_{2-2 \mathrm{xl}}(\mathrm{F})_{2 \times 1}+\left(2-2 \mathrm{x}_{1}\right) \mathrm{HF} \rightarrow \\
& \mathrm{Ca}_{10}\left(\mathrm{PO}_{4}\right)_{1-\mathrm{y}}\left(\mathrm{CO}_{3}\right)_{\mathrm{y}}^{\mathrm{y}}\left(\mathrm{PO}_{4}\right)_{5}(\mathrm{OH})_{2-\mathrm{xk}} \mathrm{F}_{\mathrm{xk}}+\left(2-\mathrm{x}_{\mathrm{k}}\right) \mathrm{HF}+\mathrm{H}_{2} \mathrm{O} ;
\end{aligned}
$$

where $x_{k}$ maximum value is 1 and $x_{1}$ minimum value is 0 .

So, the summary reaction in the reaction with total stoichiometry would be:

$$
\begin{aligned}
& 9 \mathrm{Ca}(\mathrm{OH})_{2-2 \mathrm{y}}\left(\mathrm{CO}_{3}\right)_{\mathrm{y}}+3 \mathrm{P}_{2} \mathrm{O}_{5}+\mathrm{CaF}_{2} \rightarrow \\
& \mathrm{Ca}_{10}\left(\mathrm{PO}_{4}\right)_{1-\mathrm{y}}\left(\mathrm{CO}_{3}\right)_{\mathrm{y}}\left(\mathrm{PO}_{4}\right)_{5} \mathrm{~F}_{2}+9 \mathrm{H}_{2} \mathrm{O} ; \mathrm{x}=1
\end{aligned}
$$

Based on X-ray diffraction, it was found that after only $1 \mathrm{~h}$ of mechanochemical treatment, amorphization had occurred.

Due to extremely high concentration of mechanical strain on a very small contact surface (the contact that is realized in mutual globe collision or in globe collision with the surface of the inner lining) conditions are generated for the emergence of high shear stresses in a relatively small contact surface. Thus, the size of tension strain depends primarily on the diameter of spheres used in mechanochemical treatment (the size of the contact portion of a sphere indentation deformation in a crash) and the speed collision. Simultaneously, strain transfer leads to mechanical activation of the system and highly resilient flow that follows intense chemical and phase changes in the material (reaction shift, mixing ionic types, creating new phase, etc.). These changes can be such that material during the relaxation time partly suffers reversible deformation (highly resilient flow) or can be entirely irreversible when creeping material mechanism dominates.

The tension of critical deformation depends on the system exposure time to deformation (the number of sphere blows), in other words the number of pressure cycles, so that with time, the tension which provokes critical deformation demolition/formation of fissures and new areas, has less and less value, leading to larger amorphousness of the system. The process of mechanical activation in which water appears as a reaction product, is additionally accelerated by facilitating the transport of adequate ion types to places that correspond to the minimum of free energy of the system.

In this case, because of the exceptional hydrophilicity of $\mathrm{P}_{2} \mathrm{O}_{5}$, immediately upon its adding to other reactive substances, the process creates phosphorous acid $\left(\mathrm{P}_{2} \mathrm{O}_{5}+\right.$ $3 \mathrm{H}_{2} \mathrm{O} \rightarrow 2 \mathrm{H}_{3} \mathrm{PO}_{4}$, which then reacts with $\mathrm{Ca}(\mathrm{OH})_{2-2 \mathrm{y}}\left(\mathrm{CO}_{3}\right)_{y}$ and creates $\mathrm{Ca}\left(\mathrm{HPO}_{4}\right)_{1-\mathrm{y}}\left(\mathrm{CO}_{3}\right)_{\mathrm{y}}$ (carbonate calcium hydrogen phosphate).

After $4 \mathrm{~h}$ of milling, the distinctive $\mathrm{HPO}_{4}{ }^{2-}$ start to vanish intensively and $5 \mathrm{~h}$ after completely disappears, while the band on $963 \mathrm{~cm}^{-1}$, appears (carbonate calcium efficienthydroxide fluorapatite) (Figure 1). Simultaneously, during the whole process, $\mathrm{CaF}_{2}$ dissociates and $\mathrm{F}$ ions that enter into reactionare created with calcium deficient hydroxide fluorapatite until the formation of its final chemical form. Finally, on previously mechanically treated samples during the period of 6 and 9 hours, and their afterwards thermic treatment on $1100^{\circ} \mathrm{C}$, the bands belonging to $\mathrm{CO}_{3}^{2-}$ disappear on 1420 and $1455 \mathrm{~cm}^{-1}$. In samples mechanically treated for 6 hours one band ap- 


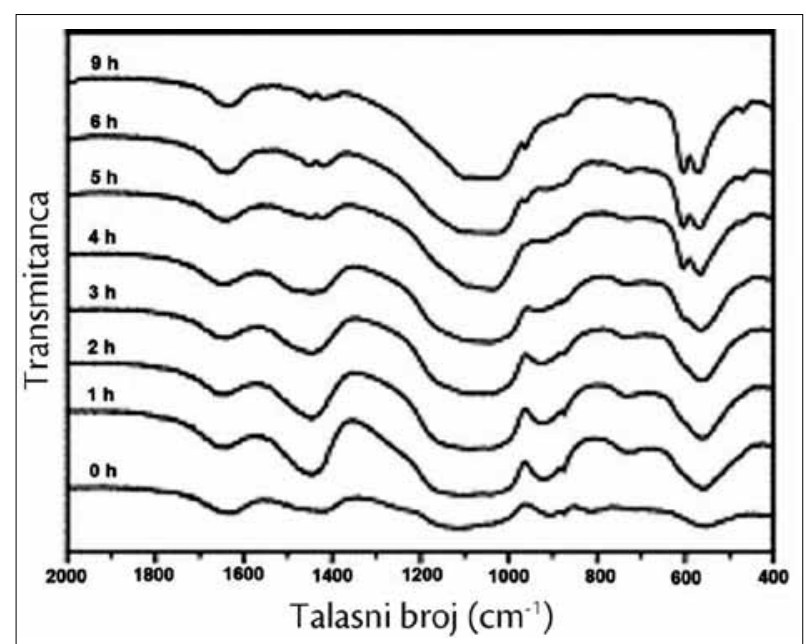

Figure 1. FTIR spectrum of untreated and mechanochemically treated mixture of $\mathrm{Ca}(\mathrm{OH})_{2}-\mathrm{P}_{2} \mathrm{O}_{5}-\mathrm{CaF}_{2}$

Slika 1. FTIR spektar netretirane i mehanohemijski tretirane smeše $\mathrm{Ca}(\mathrm{OH})_{2}-\mathrm{P}_{2} \mathrm{O}_{5}-\mathrm{CaF}_{2}$

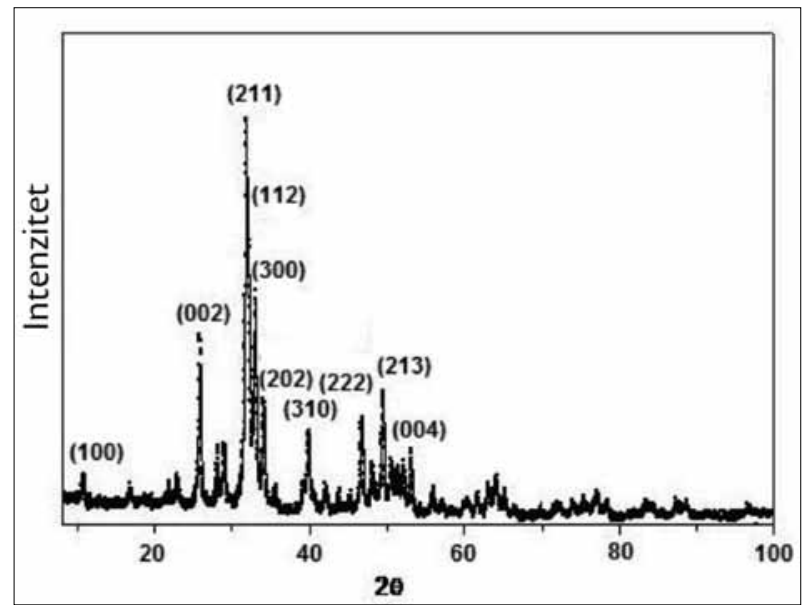

Figure 2. Refined XRD fluorapatite obtained after 9 hours of mechanochemical treatment

Slika 2. Utačnjeni XRD fluorapatita dobijenog mehanohemijskim tretmanom tokom $9 \mathrm{~h}$ pears on $630 \mathrm{~cm}^{-1}$ indicating that exchange between fluor and hydroxide group was not completed. The band on 726 $\mathrm{cm}^{-1}$ that belong to $\mathrm{F}$ ions, is constantly present during the whole process demonstrating that $\mathrm{F}$ coordination is not significantly changed through the process of $\mathrm{F}$ transfer from $\mathrm{CaF}_{2}$ into calcium hydroxide fluorapatite.

The rate of deprotonation of $\mathrm{HPO}_{4}^{2-a n d ~ i o n ~ e x c h a n g e ~}$ of $\mathrm{OH}^{-a n d} \mathrm{~F}$ regulate the rate of formation of fluorapatite in all stages of the process. The process of dissociation of calcium fluorite occurs through the process of chemical etching of its particles, within the defects of the system (open surfaces, corrosion pits, dislocations, dislocation loops, vacancies), and tears $\mathrm{Ca}^{2+}$ ions away from these places, leaving exposed F-ions which are carried by water molecules andthen transported to places that correspond to a given fluctuating concentration gradient / concentration gradient of the local surface.

This indicates that it is realistic to assume that reactions in larger and smaller initial particles of the system take place in different ways and at different time intervals reach equilibrium conditions for the final reaction of fluorapatite formation. The reaction on the surface of large particles probably runs immediately after the begining of the mechanochemical treatment, while the cores that are still associated to given initial reactants remained in the depth of the particles. The morphology of the particles, which even in the remote stages of the treatment (4-6 hours) remains the same, testifies that the reactions in every particle / particle group advance individually. The reaction in smaller particles proceeds quickly, and in medium and large particles it progresses with full intensity along the newly created paths (new surface areas, the border of the crystallites / block mosaics, etc.), until the reaction of conversion of the calcium hydroxyfluorapatite into the fluorapatite is fully implemented, as it is shown on the refined XRD spectrum (Figure 2).

Figure 3 shows the nearest neighbours of $\mathrm{F}^{-}$ion in the structure of carbonate fluorapatite. It is noted that there are three $\mathrm{CaII}^{2+}$ located near $\mathrm{F}^{-}$ion at a distance of $2.3 \AA$.

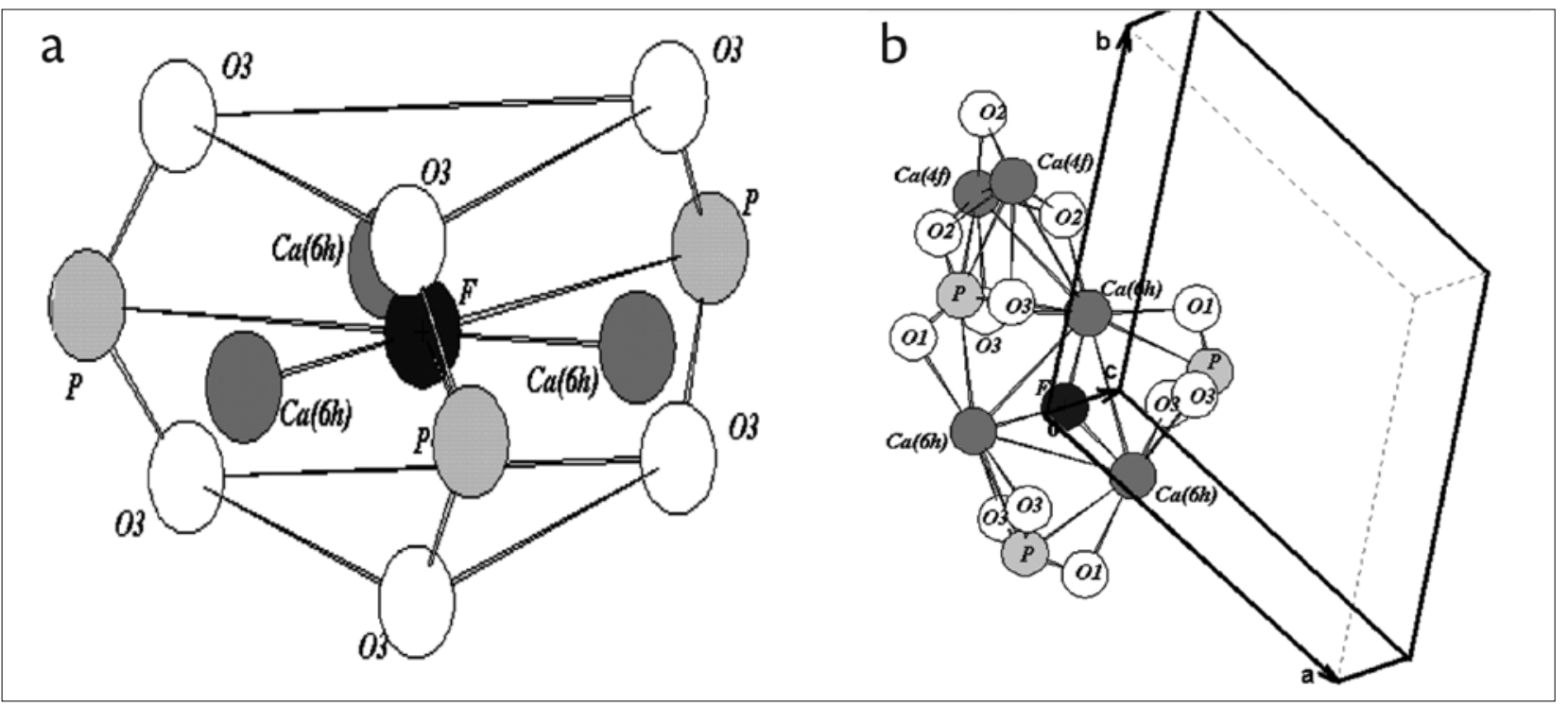

Figure 3. a) The closest neighbours of $F$ - ion in the carbonate fluoroapatite structure; $b$ ) Fragment of crystal lattice compared with a unit cell Slika 3. a) Najbliži susedi F- jona u karbonatnoj fluoroapatitnoj strukturi; b) Fragment kristalne ćelije upoređen sa jediničnom ćelijom 


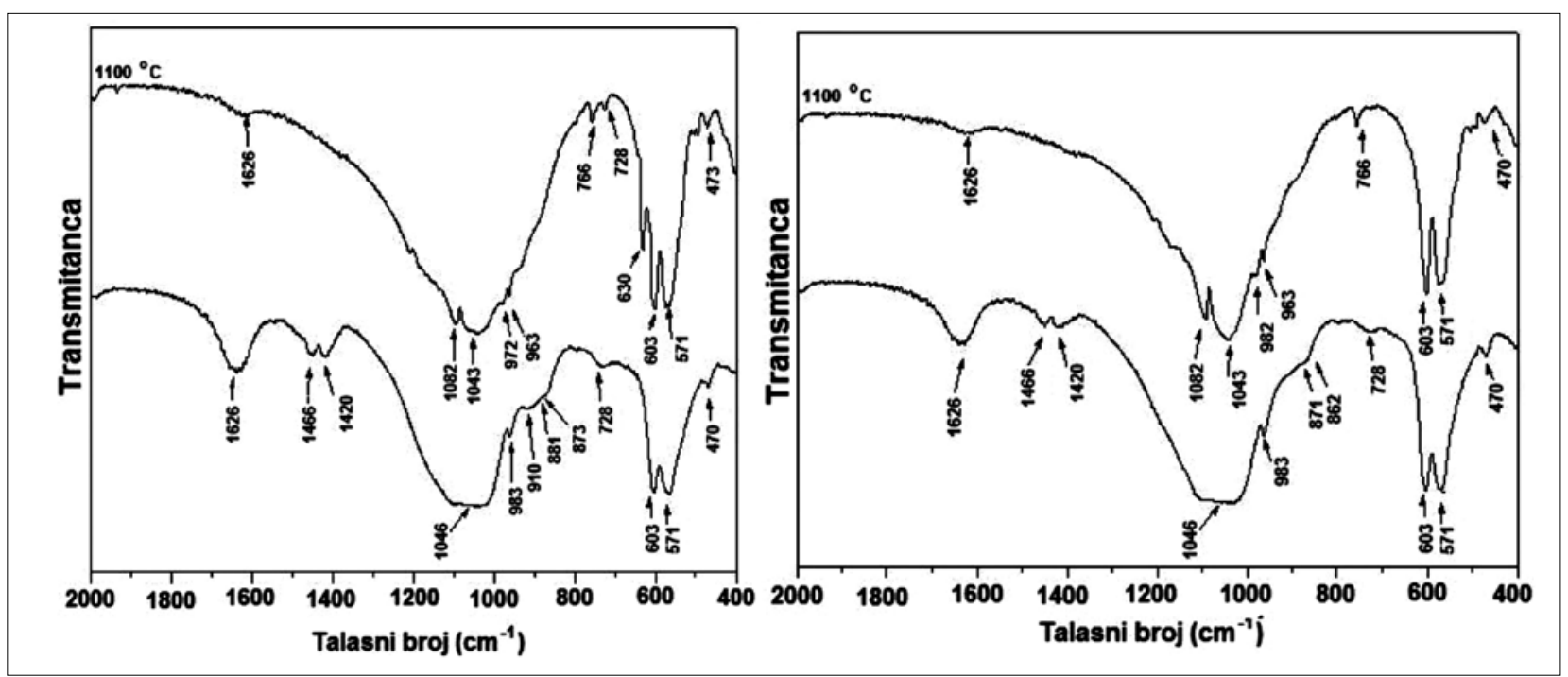

Figure 4. FTIR spectrum of mechanochemically treated mixture of $\mathrm{Ca}(\mathrm{OH}) 2-\mathrm{P} 2 \mathrm{O} 5-\mathrm{CaF} 2$ for various milling times: a) 6 hours, and b) 9 hours after and before thermal treatment

Slika 4. FTIR spektar mehanohemijski tretirane smeše $\mathrm{Ca}(\mathrm{OH}) 2-\mathrm{P} 2 \mathrm{O} 5-\mathrm{CaF} 2$ za različita vremena mlevenja: a) 6 časova i b) 9 časova posle i pre termičkog tretmana

These $\mathrm{CaII}^{2+}$ ions form the vertices of an equilateral triangle with $\mathrm{F}^{-}$ion in the center. There are three $\mathrm{CaII}^{2+}, \mathrm{P}^{5+}$, and $\mathrm{O}^{2-}$ ions in the second coordination sphere, which mutually form the vertices of triangles. The distance between $\mathrm{F}^{-}$and $\mathrm{P}^{5+}$ is $3.6 \AA$, and between $\mathrm{P}^{5+}$ and $\mathrm{O}^{2-}(1)$ is $3.9 \AA$. There are $\mathrm{O}^{2-}(3)$ ions above and below the plane containing $\mathrm{F}^{-}$and $\mathrm{CaII}^{2+}$. The oxygen ions occupy the vertices of a dodecahedron. The distance between $\mathrm{F}^{-}$and $\mathrm{O}^{2-}(3)$ ions is $3.1 \AA$, whereas between $\mathrm{P}^{5+}$ and $\mathrm{O}^{2-}(3)$ ions it is $1.5 \AA$. Figure 2 shows a fragment of the crystal lattice compared with the unit cell. According to the research of Pandaet al.CaII ${ }^{2+}$ has larger atomic size compared toCaI ${ }^{2+}$. When $\mathrm{OH}^{-}$ions are substituted with $\mathrm{F}^{-}$, there is greater distortion in the structure due to the larger size of the ionic radius of $\mathrm{F}$. At the end of the mechanochemical synthesis process, F- ion occupies large space in the center of the latticeforming a stable fluorapatite structure.

According to the research of Jokanovicet al. [24] $\left(\mathrm{OH}^{-}\right.$, $\mathrm{F}-$ ), in addition to the three types of $\left[\mathrm{OH}^{-}\right]$, the chain of apatite also contains the fourth type with different vibrational energies. It is observed in this study that if the criteria for displacement of free vibration $\mathrm{OH}^{-}$is taken as the criteria for quantifying the changes of $\mathrm{OH}^{-}$with $\mathrm{F}^{-}$, then it is indicated that about $50 \%$ of $\mathrm{OH}^{-}$groups are modified with $\mathrm{F}$, while the system, with almost completely changed $\mathrm{OH}^{-}$ groups with $\mathrm{F}^{-}$(for pure fluorapatite), provides the value of the wave number of $758 \mathrm{~cm}^{-1}$ (Figure 4 and Table 1).

\section{THE METHOD OF SYNTHESIZING WITH ADDITIONAL LOW-TEMPERATURE THERMAL TREATMENT}

Another method of mechanochemical synthesis using the precursors $\mathrm{Ca}(\mathrm{OH})_{2}, \mathrm{P}_{2} \mathrm{O}_{5} \mathrm{NH}_{4} \mathrm{~F}$ and surfactant of vinyl acetate / versatate, shows that mechanochemical process only can not form fluorapatite. That is why it is necessary to carry out an additional low-temperature treatment.
Table 1. Assignment of IR absorption bands Tabela 1. Asignacija IR apsorpcionih traka

\begin{tabular}{|c|c|c|c|c|}
\hline \multirow{2}{*}{ Mod } & \multicolumn{4}{|c|}{$\begin{array}{l}\text { Sample } \\
\text { Uzorak }\end{array}$} \\
\hline & FA $(t=6 h)$ & $F A(t=9 h)$ & $\begin{array}{c}F A(t=6 h, \\
1100 C)\end{array}$ & $\begin{array}{c}F A(t=9 h, \\
1100 \mathrm{C})\end{array}$ \\
\hline \multirow[t]{2}{*}{$\mathrm{V}_{3}(\mathrm{O}-\mathrm{H})$} & 3430 & 3430 & 3430 & 3430 \\
\hline & 2926 & 2926 & 2926 & 2926 \\
\hline$\delta(\mathrm{O}-\mathrm{H})$ & 1626 & 1626 & 1626 & 1626 \\
\hline $\mathrm{V}_{3}\left(\mathrm{CO}_{3}^{2-}\right)$ & 1455 & 1455 & - & - \\
\hline $\mathrm{V}_{3}\left(\mathrm{CO}_{3}^{2-}\right)$ & 1420 & 1420 & - & - \\
\hline $\mathrm{V}_{3}\left(\mathrm{PO}_{4}^{3-}\right)$ & 1092 & 1092 & 1093 & 1093 \\
\hline $\mathrm{V}_{3}\left(\mathrm{PO}_{4}^{3-}\right)$ & 1046 & 1042 & 1043 & 1043 \\
\hline $\mathrm{V}_{1}\left(\mathrm{PO}_{4}^{3-}\right)$ & 963 & 962 & 963 & 963 \\
\hline$V(F)$ & 726 & 726 & - & 726 \\
\hline$v_{L}(\mathrm{O}-\mathrm{H})$ & - & - & 630 & - \\
\hline $\mathrm{V}_{4}\left(\mathrm{PO}_{4}^{3-}\right)$ & 603 & 603 & 603 & 603 \\
\hline $\mathrm{V}_{4}\left(\mathrm{PO}_{4}^{3-}\right)$ & 571 & 571 & 571 & 571 \\
\hline $\mathrm{V}_{2}\left(\mathrm{PO}_{4}^{3-}\right)$ & 473 & 473 & 473 & 473 \\
\hline
\end{tabular}

FTIR method (Figure 5) proved to be the most suitable method for monitoring the synthesis. In order to obtain complete picture of phase transitions that occur in materials during mechanochemical and low-temperature treatment, the method of X-ray diffraction [23] can be used in addition to FTIR method.

XRD spectra of samples (Figure 6) show very intense peaks of portlandite $(\mathrm{P})$, while $\beta-\mathrm{Ca}_{2} \mathrm{P}_{2} \mathrm{O}_{7}(\mathrm{CP})$ peaks are also visible. In addition, $\mathrm{CaCO}_{3}(\mathrm{C})$ and $\mathrm{CaF}_{2}(\mathrm{CF})$ peaks are strongly emphasized. All the characteristic diffraction peaks for FA are almost negligible, and some of them absent [29].

After 5 minutes of milling, the most intense peaks belong to $\mathrm{Ca}(\mathrm{OH})_{2}$, and typical peaks for $\beta-\mathrm{Ca}_{2} \mathrm{P}_{2} \mathrm{O}_{7}, \mathrm{CaF}_{2}$ and $\mathrm{CaCO}_{3}$ are clearly visible. The peak corresponding to $\mathrm{Ca}(\mathrm{OH})_{2}$ is clearly visible and shows low rate of reaction for forming fluorapatite. Consequently, the amount of synthesized FA in the mixture is negligible. 


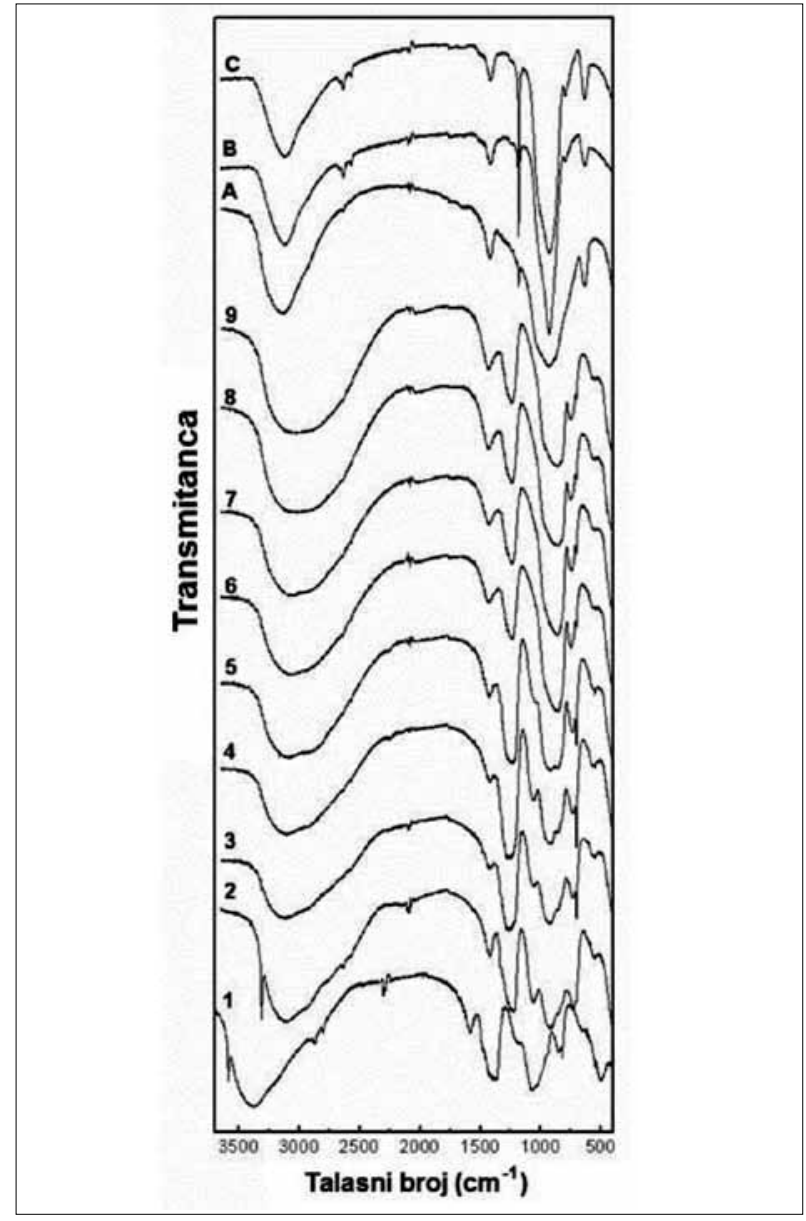

Figure 5. FTIR spectrum of $\mathrm{Ca}(\mathrm{OH})_{2}-\mathrm{P}_{2} \mathrm{O}_{5}-\mathrm{NH}_{4} \mathrm{~F}$ mechanically treated mixture: 1 - 5 minutes, 2 - 20 minutes, 3 - 35 minutes, $4-1$ hours, $5-2$ hours, $6-3$ hours, $7-4$ hours, $8-6$ hours, $9-8$ hours, A-C - thermally treated

Slika 5. FTIR spektar $\mathrm{Ca}(\mathrm{OH})_{2}-\mathrm{P}_{2} \mathrm{O}_{5}-\mathrm{NH}_{4} \mathrm{~F}$ smeše mehanički tretirane: $1-5$ min., $2-20$ min., $3-35$ min., $4-1$ h, $5-2 h, 6-3 h$, $7-4$ h, $8-6$ h, $9-8$ h, A-C - termički tretirane

There were identified changes in the structure from amorphous to crystalline, for all thermally treated samples. The typical peaks of FA confirmed transformation that took place in almost all samples (Figure 7). The amount of residual $\mathrm{CaCO}_{3}$ and $\mathrm{CaF}_{2}$ was still significant only in the sample milled for 5 minutes. The emphasized peaks of these phases indicate that parts of the samples remained unchanged, despite the high energy involved in the mechanochemical treatment during the preparation of the precursors mixture (Figure 7a).

As shown in Figure 7 a-c, clearly emphasized and sharp peaks typical for FA are present as a result of an adequate mixing of samples for 2 hours and particularly milling for 8 hours. The sample milled for 5 minutes shows that the transformation of the reaction mixture in flourapatite was only partial, despite the thermal treatment at $550^{\circ} \mathrm{C}$ for 3 hours. In addition to FA peaks, there are also $\mathrm{CaCO}_{3}$ and $\mathrm{CaF}_{2}$ peaks. This proves that even though the inside of the micelle of a surfactant contains the components of the building blocks of precursors phase that can be easily transformed into the pure fluorapatite, they still remain unchanged.

On the contrary, the mixture that was milled for at least 2 hours and additionally thermally treated for 3 hours is

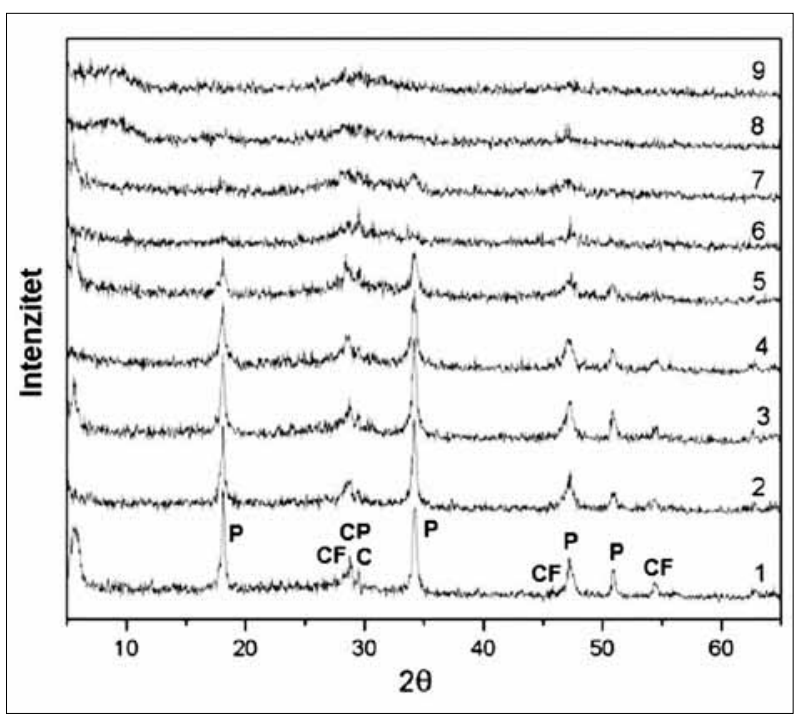

Figure 6. XRD spectrum of $\mathrm{Ca}(\mathrm{OH})_{2}-\mathrm{P}_{2} \mathrm{O}_{5}-\mathrm{NH}_{4} \mathrm{~F}$ mechanically treated mixture: $1-5$ minutes, $2-20$ minutes, $3-35$ minutes, $4-1$ hours, $5-2$ hours, $6-3$ hours, $7-4$ hours, $8-6$ hours, $9-8$ hours Slika 6. XRD spektar $\mathrm{Ca}(\mathrm{OH})_{2}-\mathrm{P}_{2} \mathrm{O}_{5}-\mathrm{NH}_{4} \mathrm{~F}$ smeše mehanički tretirane: $1-5$ min., $2-20$ min., $3-35$ min., $4-1$ h, $5-2$ h, $6-3 \mathrm{~h}$, $7-4 h, 8-6 h, 9-8 h$

completely transformed into the pure fluorapatite. Similar was for a sample that was milled for 8 hours. The peak corresponding to FA only moves towards the greater angles of diffraction. This means that the content of $\mathrm{OH}^{-}$groups was reduced during the milling of the sample and that FA finally became predominant phase (possibly mixed with a small amount of hydroxyapatite).

\section{REACTION MECHANISM}

During 5 minutes and 2 hours of milling, the reactions in which $\beta-\mathrm{Ca}_{2} \mathrm{P}_{2} \mathrm{O}_{7}$ and $\mathrm{CaF}_{2}$ are formed are dominant, while $\mathrm{Ca}(\mathrm{OH})_{2}$ part remains unchanged. This has a strong influence on the synthesis rate of FA, which is very slow and cannot be completed only by milling (even after 8 hours of milling). This low rate comes from a very slow diffusion and rearrangement of certain ions that are necessary for FA formation. The exchange and incorporation of $\mathrm{Ca}^{2+}$ ions in $\beta-\mathrm{Ca}_{2(1-x)} \mathrm{P}_{2(1-x)} \mathrm{O}_{7(1-x)}$ and $\mathrm{Ca}_{(1-x)} \mathrm{F}_{2(1-x)}$ pre-formed cells is strongly inhibited by the presence of EVA/EVV. Therefore, in order to provide bigger reaction rate of formation of FA, crystal structure of $\beta-\mathrm{Ca}_{2(1-x)} \mathrm{P}_{2(1-x)}$ $\mathrm{O}_{7(1-\mathrm{x})}$ and $\mathrm{Ca}_{(1-\mathrm{x})} \mathrm{F}_{2(1-\mathrm{x})}$ must firstly be transformed to amorphous by additional milling ( $2-8$ hours). This procedure provides good mixing, which reduces the diffusion paths of different ions.

The second stage of the formation of FA started after low temperature treatment of the samples at $550^{\circ} \mathrm{C}$ for 3 hours. In this step, according to certain researches, the reactions can be initiated on the surface of the dominant phase $\beta-\mathrm{Ca}_{2} \mathrm{P}_{2} \mathrm{O}_{7}$ through the surface diffusion of additional $\mathrm{Ca}^{2+}$ and F-ions in its volume. According to the diffraction peaks, it is evident that the process of formation of FA during these thermal treatments is very intense. The only exception was a sample milled for 5 minutes. Despite conducted thermal treatment, short milling time was not 

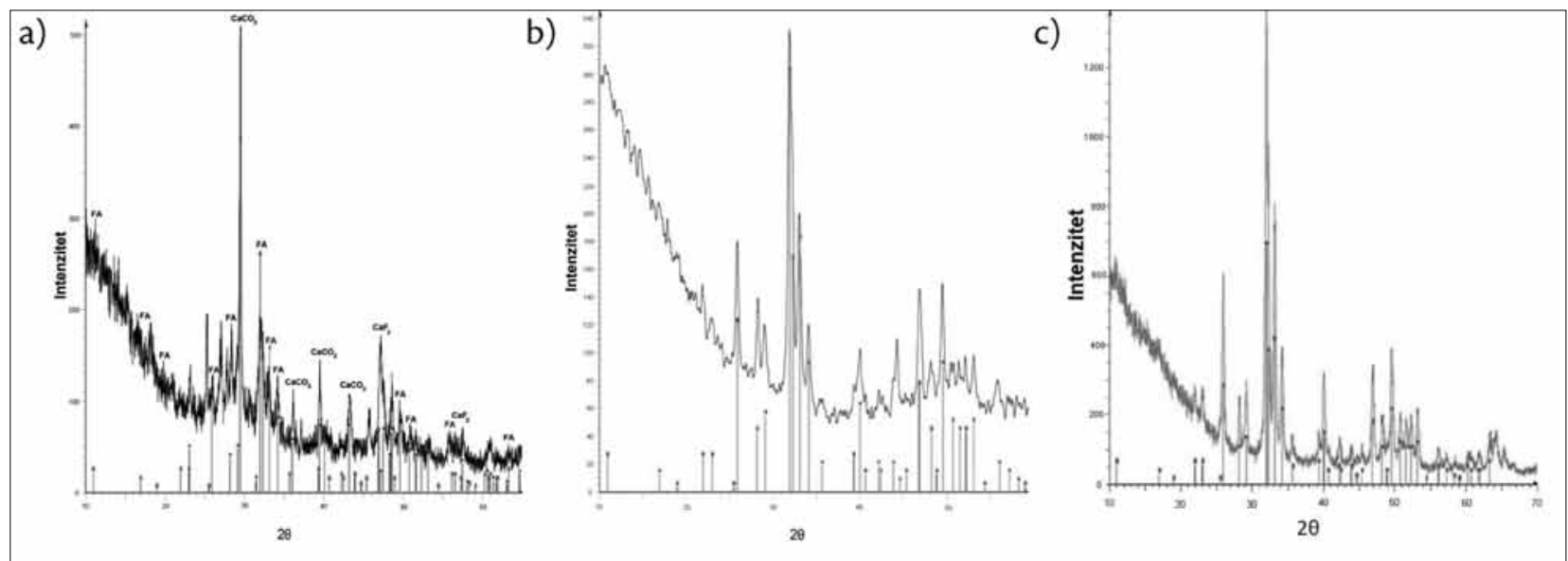

Figure 7. XRD spectra of $\mathrm{Ca}(\mathrm{OH})_{2}-\mathrm{P}_{2} \mathrm{O}_{5}-\mathrm{NH}_{4} \mathrm{~F}$ mixture after different milling times: a) 5 minutes, b) 2 hours, c) 8 hours Slika 7. XRD spektri $\mathrm{Ca}(\mathrm{OH})_{2}-\mathrm{P}_{2} \mathrm{O}_{5}-\mathrm{NH}_{4}^{2} \mathrm{~F}^{4}$ smeše nakon različitih vremena mlevenja: a) 5 min., b) $\left.2 \mathrm{~h}, \mathrm{c}\right) 8 \mathrm{~h}$

enough to obtain a single-phase system (FA). However, the milling of at least 2 hours led to the formation of pure FA phase. The presence of almost negligible peaktypical for $\beta$ - $\mathrm{Ca}_{2} \mathrm{P}_{2} \mathrm{O}_{7}$ proves that this milling time is the border time for obtainingthe single-phase FA.

It is important to emphasize that, no matter how long the samples were milled; this reaction wouldn't be possible without the thermal treatment. With the extended milling time (up to 3 hours or more), the system became amorphous. The reaction did not progress even during the longest milling time ( 8 hours), which was confirmed by $\mathrm{XRD}$. The progress was observed only in the amorphous samples (milled for at least 2 hours), which were subjected to subsequent thermal treatment. The mechanism of the process, which took place during milling, was possibly significantly activated by the water present in $\mathrm{Ca}(\mathrm{OH})_{2}$. The explanation provided by some researchers shows that smaller $\mathrm{Ca}(\mathrm{OH})_{2}$ particles, during milling under the influence of shearing forces, tend to grow, causing further disintegration [29-31], so that the exchange of different ion species becomes more efficient.

During milling, the distortion of $\mathrm{Ca}^{2+}-\mathrm{O}$ polyhedra is much more prominent in comparison with $\mathrm{P}^{5+}-\mathrm{O}$ tetrahedra. The distortion led to displacement of cations from the center of its coordination sphere. It has a strong impact on the diffusion rate of the remaining amount of $\mathrm{Ca}^{2+}$ and $\mathrm{F}-$ ions and consequent destruction of $\beta-\mathrm{Ca}_{2} \mathrm{P}_{2} \mathrm{O}_{7}$ during milling. Thus, the "empty" space in $\beta-\mathrm{Ca}_{2} \mathrm{P}_{2} \mathrm{O}_{7}$ is increasinglyfilled with these ions, until $\beta-\mathrm{Ca}_{2} \mathrm{P}_{2} \mathrm{O}_{7}$ cell is completely destroyed. It should be noted that the capacity of dissolution of $\mathrm{Ca}^{2+}$ and $\mathrm{F}^{-}$ions within $\beta-\mathrm{Ca}_{2} \mathrm{P}_{2} \mathrm{O}_{7}$ is very high. Accordingly, the smaller size of $\mathrm{CaF}_{2}$, and especially $\mathrm{Ca}(\mathrm{OH})_{2}$ crystallites is suitable for further propagation reaction of the formation of FA. Although crystallization of amorphous phase cannot be achieved through milling, the distribution of ions provides very rapid crystallization of the samples in FA in the next step of a very low thermal treatment (at $550{ }^{\circ} \mathrm{C}$ for 3 hours).

Therefore, it seems that there is enough space within $\beta-\mathrm{Ca}_{2} \mathrm{P}_{2} \mathrm{O}_{7}$ structure for $\mathrm{F}$ - anions to be placed in large gaps, and within the network of calcium and phosphate ions. In addition to $\mathrm{F}$ - ions, very small $\mathrm{CaF}_{2}$ nanoparticles are placed randomly in the gaps within $\beta-{ }^{2} a_{2} \mathrm{P}_{2} \mathrm{O}_{7}$ lattices, which produce significant changes in its symmetry, causing the corresponding chemical changes responsible for the transformation of mixture into fluorapatite during the next thermal treatment. This treatment can significantly accelerate the processes of diffusion, causing degradation of EVA/EVV micellar cages and supporting small ion redistribution by distortion in $\beta-\mathrm{Ca}_{2} \mathrm{P}_{2} \mathrm{O}_{7}$ structure induced by shear forces, until the final transformation of the mixture into fluorapatite.

\section{CONCLUSION}

Mechanochemical process of fluorapatite synthesis is based on the use of two kinds of precursors: calcium hydroxide, phosphorus pentoxide and calcium fluoride, or calcium hydroxide, phosphorus pentoxide and ammonium fluoride with the addition of surfactant vinyl acetate/verstat. On the basis of XRD and FTIR analysis it was observed that fluorapatite has significant advantages in comparison with hydroxyapatite. These benefits are related to its greater stability, lower solubility and especially better protection against cavities.

\section{APPRECIATION}

This work was supported by the Ministry of Education, Science and Technological Development of the Republic of Serbia (Project no. 172026).

\section{REFERENCES}

1. Jokanović V. Monografija: Nanomedicina, najveći izazov 21. veka, DATA STATUS, 2012.

2. Barinov SM, Shvornevab LI, Ferroc D, Fadeevaa IV, Tumanov SV. Solid solution formation at the sintering of hydroxyapatite/fluorapatite ceramics. Sci Technol Adv Mater. 2004; 5:537-41. [DOI: 10.1016/j. stam.2004.02.012]

3. Nikcevic I, Jokanovic V, Mitric M, Nedic Z, Makovec D, Uskokovic D. Mechanochemical synthesis of nanostructured fluorapatite/fluorhydroxyapatite and carbonated fluorapatite/fluorhydroxyapatite. J Solid State Chem. 2004; 177:2565-74. [DOI: 10.1016/j.jssc.2004.03.024] 
4. Quilitz M, Steingröver K, Veith $M$. Effect of the Ca/P ratio on the dielectric properties of nanoscaledsubstoichiometric hydroxyapatite. J Mater Sci Mater Med. 2009; 21:399-405.

5. Pushpakanth S, Srinivasan B, Sreedhar B, Sastry TP. An in situ approach to prepare nanorods of titania hydroxyapatite (TiO2eHAp) nanocomposite by microwave hydrothermal technique. Mater Chem Phys. 2008; 107:492-8. [DOI: 10.1016/j.matchemphys.2007.08.029]

6. Ebrahimi-Kahrizsangi R, Nasiri-Tabrizi B, Chami A. Synthesis and characterization of fluorapatiteetitania (FAp-TiO2) nanocomposite via mechanochemical process Solid State Sciences. 2010; 12:1645-51. [DOI: 10.1016/j.solidstatesciences.2010.07.017]

7. Kim H, Kim HE, Knowles JC. Fluor-hydroxyapatite sol-gel coating on titanium substrate for hard tissue implants. Biomaterials. 2004; 25:3351-8. [DOI: 10.1016/j.biomaterials.2003.09.104] [PMID: 15020107]

8. Kim H, Kong Y, Bae C, Noh Y, Kim HE. Sol-gel derived fluor-hydroxyapatite biocoatings on zirconia substrate. Biomaterials. 2004; 25:291926. [DOI: 10.1016/j.biomaterials.2003.09.074] [PMID: 14967523]

9. Cheng K, Weng W, Qu H, Du P, Shen G, Han G, et al. Sol-gel preparation and in vitro test of fluorapatite/hydroxyapatite films. J Biomed Mater Res Part B Appl Biomater. 2004; 69E:33-7. [DOI: 10.1002/ jbm.b.20027]

10. Yoon BH, Kim HW, Lee SH, Bae C), Koh YH, Kong YM, et al. Stability and cellular responses to fluorapatite-collagen composites. Biomaterials. 2005; 26:2957-63. [DOI: 10.1016/j.biomaterials.2004.07.062]

11. Cheng K, Weng W, Wang H, Zhang S. In vitro behavior of osteoblast like cells on fluoridated hydroxyapatite coatings. Biomaterials. 2005; 26:6288-95. [DOI: 10.1016/j.biomaterials.2005.03.041] [PMID: 15913766]

12. Zhang H, Zhu Q, Xie Z. Mechanochemical-hydrothermal synthesis and characterization of fluoridated hydroxyapatite. Mater Res Bull. 2005; 40:1326-34. [DOI: 10.1016/j.materresbull.2005.04.005]

13. Rølla G. On the role of calcium fluoride in the cariostatic mechanism of fluoride. Acta Odontol Scan.1988; 46:341-5. [PMID: 3063053]

14. Lagerlof F, Ekstrand ), Rolla G. Effect of fluoride addition on ionized calcium in salivary sediment and in saliva. Scand I Dent Res. 1988; 96:399-404. [PMID: 3201111]

15. Rølla G, Saxegard E. Critical evaluation of the composition and use of topical fluorides with emphasis on the role of calcium fluoride in caries inhibition. J Dent Res. 1990; 69:780-5. [PMID: 2179341]

16. Zahrani EM, Fathi $M H$. The effect of high-energy ball milling parameters on the preparation and characterization of fluorapatite nanocrystalline powder. Ceramics International. 2009; 35:2311-323. [DOI: 10.1016/j.ceramint.2009.01.012]

17. Azami M, Jalilifiroozinezhad S, Mozafari M, Rabiee M. Synthesis and solubility of calcium fluoride/hydroxy-fluorapatitenanocrystals for dental applications. Ceramics International. 2011; 37:2007-14. [DOI: 10.1016/j.ceramint.2011.02.025]

18. Saxegaard E, Rølla G. Kinetics of acquisition and loss of calcium fluoride by enamel in vivo. Caries Res. 1989; 23:406-11. [PMID: 2598228]
19. Rodriguez-Lorenzo LM, Gross KA. Encapsulation of apatite particles for improvement in bone regeneration. J Mater Sci: Mater in Med. 2003; 14:1-5.

20. Chow LC, Takagi S. Deposition of fluoride on tooth surfaces by a two-solution mouth rinse in vitro. Caries Res. 1991; 25:397-401. [PMID: 1810650]

21. Vogel GL, Mao Y, Carey CM, Chow LC, Takagi S. In vivo fluoride concentrations measured for two hours after a NaF or a new two-solution rinse. J Dent Res. 1992; 71:448-452. [DOl: 10.1177/00220345920710030501] [PMID: 1573075]

22. Chow LC, Takagi S, Carey CM, Sieck BA. Remineralization effects of a two-solution fluoride mouthrinse: An in situ study. J Dent Res. 2000; 79:991-995. [DOI: 10.1177/00220345000790041601] [PMID 10831103]

23. Chow LC, Takagi S, Frukhtbeyn S, Sieck S, Parry EE, Liao NS, et al. Remineralization effect of a low-concentration fluoride rinse in an intraoral model. Caries Res. 2002; 36:136-141. [DOI: 10.1159/000057872]

24. Jokanovic V, Colovic B, Jovic N, Babic-Stojic B, Jokanovic B. Mechanochemical and Low-Temperature Synthesis of Nanocrystalline Fluorohydroxyapatite/Fluorapatite. Int JAppl Ceram Technol. 2013; 10:959-69. [DOI: 10.1111/j.1744-7402.2012.02821.x]

25. Lau KH, Baylink DJ. Osteoblastic tartrate-resistant acid phosphatase: its potential role in the molecular mechanism of osteogenic action of fluoride. J Bone Miner Res. 2003; 18:1897-900. [DOl: 10.1359/ jbmr.2003.18.10.1897] [PMID: 14584902]

26. Riggs BL, Ofallon WM, Lane A, Hodgson SF, Wahner HW, Muhs J, et al. Clinical trial of fluoride therapy in postmenopausal osteoporotic women: extended observations and additional analysis. J Bone Miner Res. 1994; 9(2):265-275. [DOI: 10.1002/jbmr.5650090216] [PMID: 8140940]

27. Haguenauer D, Welch V, Shea B, Tugwell B, Adachi JD, Wells G Fluoride for the treatment of postmenopausal osteoporotic fractures: a meta-analysis. Osteoporos Int. 2000; 9:727-38. [DOI: 10.1007/ s001980070051] [PMID: 11148800]

28. Guanabens N, Farrerons J, Erez-Edo PL, Monegal A, Renau A, Carbonell J, et al. Cyclical etidronate versus sodium fluoride in established postmenopausal osteoporosis: a randomized 3 year trial. Bone. 2000; 27:123-8. [DOI: 10.1016/S8756-3282(00)00303-3] [PMID: 10865219]

29. Caverzasio J, Palmer G, Bonjour JP. Fluoride: Mode of Action. Bone 1998; 22:585-9. [DOI: 10.1016/S8756-3282(98)00058-1] [PMID: 9626396]

30. Bian J), Kim DW, Hong KS. Phase Transformation and Sintering Behavior of Ca2P2O7. Mater Lett. 2004; 58:347-51. [DOI: 10.1016/S0167577X(03)00498-1]

31. Yoshiyuki $\mathrm{H}$. Computational study of the solid-state vibrations and force field of magnesium and calcium hydroxides. I Braz Chem Soc. 2006; 17:741-5. [DOl: 10.1590/S0103-50532006000400016]

Received: 19.01.2016 • Accepted: 30.03.2016 


\title{
Strukturne karakteristike i mehanizmi mehanohemijske sinteze fluorapatita
}

\author{
Vukoman Jokanović1, Božana Čolović1, Marija Sandić-Živković , Marijana Popović-Bajićz, Slavoljub Živković \\ 'Univerzitet u Beogradu, Institut za nuklearne nauke „Vinča“, Beograd, Srbija; \\ ${ }^{2}$ Univerzitet u Beogradu, Stomatološki fakultet, Beograd, Srbija
}

\begin{abstract}
KRATAK SADRŽAJ
U radu su analizirani mehanizmi mehanohemijske sinteze fluorapatita i njegove strukturne karakteristike. Suštinu istraživanja čine istraživanja V. Jokanovića i saradnika objavljena u odgovarajućim časopisima i knjizi Nanomedicina, najveći izazov 21. veka. Karakteristike dobijenih materijala pokazuju njihove brojne biološke prednosti, koje su povezane sa specifičnostima strukturnog dizajna materijala tokom procesa sinteze.

Kao osnove za proučavanje procesa sinteze i mehanizma nastajanja fluorapatita korišćene su metode rendgenske difrakcije (XRD) i infracrvene spektroskopije sa Furijeovom transformacijom (FTIR).

Ključne reči: fluoroapatit; mehanohemijska sinteza; difrakcija X zraka; infracrvena spektroskopija; tretman niskom temperaturom
\end{abstract}

\section{UVOD}

Fluorapatit (FA), hemijske formule $\mathrm{Ca}_{5}\left(\mathrm{PO}_{4}\right)_{3} \mathrm{~F}$, ili Ca $\mathrm{Ca}_{10}\left(\mathrm{PO}_{4}\right)_{6} \mathrm{~F}_{2}$, najstabilniji je, najmanje rastvorljiv i najtvrđi kalcijum-ortofosfatni mineral (tvrdoća po Mosu 5). Takve osobine fluorapatita povezane su sa specifičnom pozicijom $\mathrm{F}^{-}$jona $\mathrm{u}$ centru $\mathrm{Ca}_{2}$ trougla, njegove kristalne strukture. Tehnike sinteze su slične kao kod hidroksiapatita, s tim što sinteza podrazumeva prisustvo $\mathrm{F}$ - jona, koji se unose u sintezu preko $\mathrm{CaF}, \mathrm{NaF}$ ili $\mathrm{NH}_{4}$ F. Za razliku od hidroksiapatita (HA) deficijentnog kalcijumom, nema podataka o fluorapatitima deficijentnim kalcijumom. Hemijska formula fluorapatita je $\mathrm{Ca}_{10}\left(\mathrm{PO}_{4}\right)_{6}(\mathrm{~F}, \mathrm{OH})_{2}$, zbog toga što najčešće izmena $\mathrm{OH}^{-}$jona $\mathrm{F}^{-}$jonima nije potpuna. Među svim kalcifikovanim tkivima čoveka, najveća koncentracija fluorapatita nađena je u kostima, a najmanja u zubnoj gleđi. Ipak, čak i tamo gde je najveća koncentracija fluorapatita, količina fluorida je najčešce smanjena u odnosu na stehiometrijsku količinu. Zbog svoje slabe rastvorljivosti (brzine degradacije) retko se koristi kao zamenik kostiju.

Poslednjih godina fluorohidroksiapatit/fluorapatit (FHA/ FA) koristi se u kliničkoj restauraciji, jer mu je zahvaljajući mehaničkoj stabilnosti smanjena rastvorljivost i unapređena proliferacija ćelija koštanog tkiva $[1,2]$. Pored toga, HA i FHA/ FA se koriste u biomedicini kao nosači lekova ikatalizatora i adsorbensi $[3,4]$.

Takođe, FHA/FA ima bolju termičku i hemijsku stabilnost od HA [1]. Ovaj fenomen je opisao Elliott sa saradnicima [5, 6]. Kada se određeni broj $\mathrm{OH}^{-}$grupa u HA matriksu zameni jonima F, termička i hemijska stabilnost FHA/FA keramika značajno raste. Teorijski, odnos $\mathrm{F}: \mathrm{OH} \geq 1$ unutar $\mathrm{OH}$ lanaca (u FHA strukturi) bio bi dovoljan da uredi HA kristale, stabilišući njihovu strukturu zahvaljujući naizmeničnom rasporedu F-jona između $\mathrm{OH}^{-}$jona.

U praksi se materijali koji sadrže jone F-široko koriste za stomatološke restauracije, jer sprečavaju razvoj karijesa i smanjuju bakterijsku aktivnost u kiseloj sredini. Pored toga, sami F- joni favorizuju mineralizaciju i kristalizaciju kalcijum-fosfata tokom formiranja kosti [7]. Osim toga, in vitro istraživanja FHA/FA ukazala su na njegovo sporo rastvaranje, bolje taloženje sloja sličnog hidroksiapatitu, bolju adsorbciju proteina [6-8] i uporedivo ili bolje vezivanje ćelija u poređenju sa čistim HA [7, 9], odnosno poboljšanu aktivnost alkalne fosfataze [6].
Takođe je pokazano da prisustvo fluorida utiče na povećanje količine i kvaliteta kostiju u organizmu [5]. Fluoridni jon se koristi za lečenje osteoporoze, jer koštana masa raste sa primenom F- jona [9], a F- joni stimulišu aktivnost osteoblasta, i u in vitro i u in vivo uslovima. Osim toga, mineralna faza zubne gleđi sastoji se od HA (95-97\%) sa 0,04-0,07 tež. \% fluorida. Doza od oko 1.5-4 mg fluorida dnevno značajno smanjuje rizik od karijesa [5]. Pored FHA i FHA faza, materijali slični $\mathrm{CaF}_{2}$ takođe su značajni u stomatologiji, jer mogu da se koriste kao rezervoari labilnog fluorida u prevenciji karijesa [10-14].

Neke studije su pokazale da je dvostruki sistem isporuke $\mathrm{F}^{-} \mathrm{i}$ $\mathrm{Ca}^{2+}$ jona neophodan da se omogući homogena nukleacija i formiranje vrlo malih $\mathrm{CaF}_{2}$ kristala u ustima. Ove količine su veoma efikasne u povećanju taloženja i zadržavanju labilnih $\mathrm{F}^{-}$jona u ustima, uz istovremeno povećanje efekata remineralizacije, bez konsekventnog povećanja $\mathrm{F}$ - sadržaja [15-23]. Zbog toga je $\mathrm{u}$ istraživanjima V. Jokanovića i saradnika [24] prvi put opisan ne samo specifičan način sinteze fluorapatita već i sinteze kombinovanih sistema inkapsuliranih u površinski aktivnu supstancu polietilen vinil acetat/versatat, koja je potencijalni izvor labilne $\mathrm{CaF}_{2}$ faze. Ovo je veoma važno za održavanje ravnoteže sadržaja jona $\mathrm{F}$, ali i za unapređenje hemijske i mehaničke stabilnosti zuba.

Za sintezu FHA/FA, kao što je precipitacija, koriste se različite metode, kao što susol-gel, hidroliza, hidrotermalna metoda, kao i čvrsto fazne reakcije, koje podrazumevaju odgovarajuću izmenu jona između reaktanata, koji se koriste u sintezi FA [2326]. Većina hemijskih metoda zahteva vrlo preciznu kontrolu parametara procesa sinteze, sastav proizvoda i njegove osobine, što nije tako lako postići, pa zato navedene metode nisu pogodne za sintezu FHA/FA na industrijskoj skali [27].

$S$ druge strane, mehanohemijska obrada, kao jednostavna metoda koja se odvija u čvrstom stanju, omogućava sintezu materijala kroz izuzetno efikasan proces mešanja različitih jonskih vrsta, zahvaljujući silama smicanja, koje redukcijom veličine čestica i njihovim naizmeničnim slojevitim pozicioniranjem poboljšavaju termodinamiku i kinetiku reakcija između različitih prekursora čvrste supstance. Osim toga, u poređenju sa drugim gorenavedenim procesima, ovo je pogodnija metoda i sa ekonomske i sa tehničke tačke gledišta, jer omogućava masovnu proizvodnju nanokristalnih prahova i veliku fleksibilnost procesnih parametara [13]. 
Zbog toga, cilj ovog rada je bio da se predstavi suština metode sinteze nanopraha fluorhidroksiapatita/fluorapatita metodom mehaničkog legiranja.

Parametri mlevenja, kao što su brzina rotacije, prečnik i broj kugli, maseni odnos kugle-prah, bili su konstantni, dok je uticaj vremena mlevenja na sastav faze veoma pažljivo određen. Kinetika i mehanizam reakcije za dobijanje FHA/FA i druge prelazne faze su ispitivani koristeći XRD i FTIR spektroskopiju.

\section{MEHANIZMI SINTEZE FLUORAPATITA}

Tipični mehanizmi sinteze fluorapatita prikazani su na primeru najčešće primenjivanih postupaka mehanohemijske sinteze iz najčešće korišćenih prekursora kao što su kalcijumhidroksid - $\mathrm{Ca}(\mathrm{OH})_{2}$, fosfor-pentoksid - $\mathrm{P}_{2} \mathrm{O}_{5}$ i kalcijum-fluorid - $\mathrm{CaF}_{2}$ ( sinteza 1) i kalcijum-hidroksid - $\mathrm{Ca}(\mathrm{OH})_{2}$, fosfor-pentoksid - $\mathrm{P}_{2} \mathrm{O}_{5}$, i amonijum-fluorid - $\mathrm{NH}_{4} \mathrm{~F}$, uz dodatak površinski aktivne supstance vinil acetat/versatata (EVA/AVV) (sinteza 2). Oba mehanizma odvijaju se kroz niz procesnih faza, koje je moguće pratiti na adekvatan način prvenstveno primenom IR spektroskopije i rendgenske difrakcije [24]. Na osnovu rezultata izvedenih analiza uočeno je da svaku fazu prati određeni stepen transformacije polaznih reaktanata u fluorhidroksiapatit, sa sve manjim i manjim udelima $\mathrm{OH}^{-}$grupe i sve većim i većim udelima jona $\mathrm{F}^{-}$umesto $\mathrm{OH}^{-}$grupe, sve do potpune transformacije sistema u fluorpatit.

Reakcija se u osnovi odvija sa nepotpunom stehiometrijom, pri čemu se vrednost $x$, koja definiše odstupanje od potpune simetrije, nalazi $\mathrm{u}$ intervalu $\mathrm{x}_{1}<\mathrm{x}<\mathrm{x}_{\mathrm{k}}$,

$$
\begin{aligned}
& \mathrm{Ca}_{10}\left(\mathrm{PO}_{4}\right)_{1-\mathrm{y}}\left(\mathrm{CO}_{3}\right)_{\mathrm{y}}\left(\mathrm{PO}_{4}\right)_{5}(\mathrm{OH})_{2-2 \mathrm{x}}(\mathrm{F})_{2 \times 1}+\left(2-2 \mathrm{x}_{1}\right) \mathrm{HF} \rightarrow \\
& \mathrm{Ca}_{10}\left(\mathrm{PO}_{4}\right)_{1-\mathrm{y}}\left(\mathrm{CO}_{3}\right)_{\mathrm{y}}\left(\mathrm{PO}_{4}\right)_{5}(\mathrm{OH})_{2-\mathrm{xk}}^{-\mathrm{F}_{\mathrm{xk}}}+\left(2-\mathrm{x}_{\mathrm{k}}\right) \mathrm{HF}+\mathrm{H}_{2} \mathrm{O} ;
\end{aligned}
$$

pri čemu $\mathrm{x}_{\mathrm{k}}$ može imati maksimalnu vrednost $1, \mathrm{a} \mathrm{x}_{1}$ minimalnu vrednost 0 .

Dakle, sumarna reakcija, kod reakcije sa potpunom stehiometrijom, imala bi oblik:

$9 \mathrm{Ca}(\mathrm{OH})_{2-2 \mathrm{y}}\left(\mathrm{CO}_{3}\right)_{\mathrm{y}}+3 \mathrm{P}_{2} \mathrm{O}_{5}+\mathrm{CaF}_{2} \rightarrow \mathrm{Ca}_{10}\left(\mathrm{PO}_{4}\right)_{1-\mathrm{y}}\left(\mathrm{CO}_{3}\right)_{\mathrm{y}}$ $\left(\mathrm{PO}_{4}\right)_{5} \mathrm{~F}_{2}+9 \mathrm{H}_{2} \mathrm{O} ; \mathrm{x}=1$

Na osnovu rendgenske difrakcije utvrđeno je da je već posle $1 \mathrm{~h}$ mehanohemijskog tretmana došlo do amorfizacije sistema/ mešavine.

Naime, zbog izuzetno visoke koncentracije mehaničkih naprezanja na veoma maloj površini kontakta (kontakt koji se ostvaruje pri međusobnom sudaru kugli ili sudaru kugli sa površinom unutrašnje obloge), ostvaruju se uslovi za nastajanje visokih smicajnih naprezanja na relativno maloj površini kontakta. Pri tome veličina napona deformacije zavisi prvenstveno od prečnika kugli koje se koriste kod mehanohemijskog tretmana (veličina kontaktne kalote utiskivanja deformacije pri sudaru) i brzine sudara. Istovremeno sa procesom prenosa deformacije dolazi do mehaničke aktivacije sistema i visokoelastičnog toka, koji prati intenzivne hemijske i fazne promene unutar materijala (reakcije izmene, mešanja jonskih vrsta, nastajanja novih faza itd.). Ove promene mogu biti takve da materijal tokom relaksacije delimično trpi povratnu deformaciju (viskoelastični tok), ili su pak u celosti nepovratne, kada dominira mehanizam puzanja materijala.

Napon kritične deformacije zavisi od vremena izlaganja sistema deformaciji (broja udara kugli), odnosno broja ciklusa opterećenja, tako da vremenom napon koji izaziva kritičnu deformaciju razaranja/formiranja pukotina i novih površina ima sve manju i manju vrednost, što vodi sve većoj amorfizaciji sistema. Proces mehaničke aktivacije u sistemima u kojima kao reakcioni produkt nastaje voda dodatno je ubrzan time što je olakšan transport odgovarajućih jonskih vrsta na mesta koja odgovaraju minimumu slobodne energije sistema.

$\mathrm{U}$ ovom slučaju, zbog izuzetne hidrofilnosti $\mathrm{P}_{2} \mathrm{O}_{5}$ odmah po njegovom dodavanju ostatku reakcione smeše dolazi do nastanka fosforne kiseline $\left(\mathrm{P}_{2} \mathrm{O}_{5}+3 \mathrm{H}_{2} \mathrm{O} \rightarrow 2 \mathrm{H}_{3} \mathrm{PO}_{4}\right)$, koja potom reaguje sa $\mathrm{Ca}(\mathrm{OH})_{2-2 \mathrm{y}}\left(\mathrm{CO}_{3}\right)_{\mathrm{y}}$ i nastaje $\mathrm{Ca}\left(\mathrm{HPO}_{4}\right)_{1-\mathrm{y}}\left(\mathrm{CO}_{3}\right)_{\mathrm{y}}$ (karbonatni kalcijum-hidrogenfosfat).

Nakon $4 \mathrm{~h}$ mlevenja karakteristične trake $\mathrm{za} \mathrm{HPO}_{4}{ }^{2-}$ počinju intenzivno da iščezavaju, a nakon $5 \mathrm{~h}$ potpuno iščezavaju, a pojavljuje se traka na $963 \mathrm{~cm}^{-1}$ (karbonatni kalcijum-deficijentni hidroksifluorapatit) (Slika 1). Istovremeno tokom celog procesa dolazi i do disocijacije $\mathrm{CaF}_{2}$, pri čemu nastaju joni $\mathrm{F}^{-}$koji tokom celog procesa ulaze u reakciju sa deficijentnim kalcijum-hidroksifluorapatitom sve do formiranja njegove konačne hemijske forme. Napokon, na uzorcima koji su termički tretirani na $1100^{\circ} \mathrm{C}$, a prethodno mehanički tretirani 6 i $9 \mathrm{~h}$ iščezavaju trake na 1420 i $1455 \mathrm{~cm}^{-1}$, koje pripadaju $\mathrm{CO}_{3}^{2-}$, a kod uzorka koji je mehanički tretiran $6 \mathrm{~h}$ pojavljuje se traka na $630 \mathrm{~cm}^{-1}$, koja govori da nije došlo do kraja reakcije izmene fluora i hidroksilne grupe. Traka na $726 \mathrm{~cm}^{-1}$ pripada jonima F i konstantno je prisutna tokom celokupnog procesa, što govori o tome da se kordinacija $\mathrm{F}^{-}$ne menja bitno kroz sam proces transfera $\mathrm{F}^{-}$iz $\mathrm{CaF}_{2}$ u kalcijum-hidroksifluorapatit.

Brzina deprotonizacije $\mathrm{HPO}_{4}^{2-}$ i jonske izmene $\mathrm{OH}^{-}$i F- regulišu brzinu nastajanja fluorapatita u svim fazama procesa. Proces disocijacije kalcijum-fluorita odvija se kroz proces hemijskog nagrizanja njegovih čestica, u okviru defekata sistema (otvorene površine, jamice nagrizanja, dislokacije, dislokacijske petlje, vakancije), čime se otkidaju joni $\mathrm{Ca}^{2+}$ sa tih mesta ostavljajući ogoljene jone $\mathrm{F}^{-}$koji se tek u tom trenutku nošeni molekulima vode transportuju na mesta koja odgovaraju datom fluktuacionom koncentracionom gradijentu / koncentracionom gradijentu lokalne površine.

To ukazuje da je realno pretpostaviti da se reakcija u većim i manjim polaznim česticama sistema odvija na različit način i da u različitim vremenskim intervalima doseže ravnotežne uslove za krajnju reakciju nastajanja fluorapatita. U velikim česticama verovatno reakcija na površini teče odmah po početku mehanohemijskog tretmana, dok u dubini čestica ostaju jezgra koja su još uvek pripadajuća datim polaznim reaktantima. Sama morfologija čestica, koja i u udaljenim fazama tretmana (4-6 h) ostaje ista, svedoči o tome da reakcija u svakoj čestici / grupi čestica napreduje na individualan način. $U$ manjim česticama reakcija se odvija brzo, u srednjim česticama i posebno u velikim ona napreduje punim intenzitetom duž novootvorenih puteva (novih površina, granica kristalita / blok mozaika itd.), sve dok se u celosti ne realizuje reakcija transformacije kalcijum-hidroksifluorapatita u fluorapatit, kao što je pokazano na utačnjenom XRD spektru (Slika 2).

Slika 3. pokazuje najbliže susede $\mathrm{F}^{-}$jona u strukturi karbonatnog fluorapatita. Uočava se da se tri CaII ${ }^{2+}$ nalaze u neposrednoj blizini $\mathrm{F}^{-}$jona na rastojanju od 2,3 $\mathrm{A}$. Ovi CaII ${ }^{2+}$ joni formiraju temena jednakostraničnog trougla sa $\mathrm{F}^{-}$jonom u centru. $\mathrm{U}$ drugoj koordinacionoj sferi nalaze se po tri CaII ${ }^{2+}, \mathrm{P}^{5+} \mathrm{i} \mathrm{O}^{2-}$ jona koja međusobno formiraju temena trouglova. Rastojanje 
između F- i $\mathrm{P}^{5+}$ je 3,6 , a između $\mathrm{P}^{5+}$ i O$^{2-}(1)$ je 3,9. $\mathrm{O}^{2-}(3)$ jona nalaze se ispod i iznad ravni koja sadrži F- i CaII ${ }^{2+}$. Kiseonični joni zauzimaju temena dodekaedrona. Rastojanje između $\mathrm{F}^{-} \mathrm{i}$ $\mathrm{O}^{2-}(3)$ jona je $3,1 \AA$, dok je između $\mathrm{P}^{5+} \mathrm{i} \mathrm{O}^{2-}(3)$ jona $1,5 \AA$. Slika $2 \mathrm{~b}$ pokazuje fragment kristalne rešetke upoređen sa jediničnom ćelijom. Saglasno istraživanjima Pande i njegovih saradnika, $\mathrm{CaII}^{2+}$ ima veću atomsku veličinu nego $\mathrm{CaI}^{2+}$. Kada su $\mathrm{OH}^{-}$joni supstituisani sa $\mathrm{F}^{-}$dolazi do veće distorzije u strukturi zbog veće veličine jonskog radijusa $\mathrm{F}^{-}$. Na kraju mehanohemijskog procesa sinteze $\mathrm{F}^{-}$jon zauzima veliki prostor u centru rešetke, formirajući na taj način stabilnu fluorapatitnu strukturu.

Saglasno istraživanjima V. Jokanovića i saradnika [24] $\left(\mathrm{OH}^{-}\right.$, $\mathrm{F})$, lanac apatita sadrži pored tri tipa $\left[\mathrm{OH}^{-}\right]$i četvrti tip sa različitim vibracionim energijama. $U$ ovim istraživanjima uočeno je da, ako se kao kriterijum kvantifikacije izmene $\mathrm{OH}^{-}$sa $\mathrm{F}^{-}$uzme kriterijum pomeranja slobodne vibracije $\mathrm{OH}^{-}$, sledi da je oko $50 \% \mathrm{OH}^{-}$grupa izmenjeno sa $\mathrm{F}^{-}$, dok je kod sistema sa skoro potpuno izmenjenim $\mathrm{OH}^{-}$grupama sa $\mathrm{F}^{-}$(kod čistog fluorapatita) vrednost talasnog broja od $758 \mathrm{~cm}^{-1}$ (Slika 4 i tabela 1).

\section{POSTUPAK SINTEZE SA DODATNIM NISKOTEMPERATURNIM TERMIČKIM TRETMANOM}

Drugi postupak mehanohemijske sinteze, koji je izveden primenom prekursora $\mathrm{Ca}(\mathrm{OH})_{2}, \mathrm{P}_{2} \mathrm{O}_{5}, \mathrm{NH}_{4} \mathrm{~F}$ i površinski aktivne supstance vinil acetata/versatata, pokazuje da samo u mehanohemijskom postupku nije moguće dobiti fluorapatit, nego da je za tu svrhu potrebno izvesti dodatni niskotemperaturni tretman.

Kao najadekvatnija metoda za praćenje same sinteze pokazala se kao i u prethodnom primeru FTIR metoda (Slika 5).Radi dobijanja kompletne slike o faznim prelazima koji se događaju u materijalu tokom mehanohemijskog i niskotemperaturnog tretmana, pored FTIR metode korišćena je i metoda rendgenske difrakcije, koje su detaljno opisane u referenci 23.

XRD spektri uzoraka (Slika 6) pokazuju vrlo intenzivne pikove portlandita $(\mathrm{P})$, dok su pikovi $\beta-\mathrm{Ca}_{2} \mathrm{P}_{2} \mathrm{O}_{7}(\mathrm{CP})$ takođe vidljivi. Osim toga, veoma su naglašeni i pikovi $\mathrm{CaCO}_{3}(\mathrm{C}) \mathrm{i} \mathrm{CaF}_{2}(\mathrm{CF})$. Svi karakteristični difrakcioni pikovi za FA su gotovo zanemarljivi, a neki od njih su odsutni [29].

Posle pet minuta mlevenja, najintenzivniji vrhovi pripadaju $\mathrm{Ca}(\mathrm{OH})_{2}$, a pikovi karakteristični za $\beta-\mathrm{Ca}_{2} \mathrm{P}_{2} \mathrm{O}_{7}, \mathrm{CaF}_{2}$ i CaCO jasno su vidljivi. Pik koji odgovara $\mathrm{Ca}(\mathrm{OH})_{2}$ je jasno vidljiv $\mathrm{i}$ pokazuje nisku brzinu reakcije formiranja fluorapatita. Usled toga, količina sintetisanog FA u smeši je zanemarljiva.

Za sve termički tretirane uzorke identifikovane su promene u strukturi od amorfne do kristalinične. Karakteristični pikovi FA potvrđuju transformacije koji su se desile u gotovo svim uzorcima (Slika 7). Samo u uzorku mlevenom pet minuta količina rezidualnog $\mathrm{CaCO}_{3}$ i $\mathrm{CaF}_{2}$ je bila još značajna. Izraženi pikovi ovih faza ukazuju da su delovi uzoraka ostali nepromenjeni, pored visoke energije uključene u mehanohemijski tretman prilikom pripreme smeše prekursora (Slika 7a).

Kao što je prikazano na slici $7 \mathrm{a}-\mathrm{c}$, vrlo izraženi i oštri vrhovi karakteristični za FA prisutni su kao posledica adekvatnog mešanja uzorka u toku $2 \mathrm{~h}$ i posebno $8 \mathrm{~h}$ mlevenja. Uzorak mleven pet minuta pokazuje da je transformacija reakcione smeše u fluorapatit samo delimična, uprkos termičkom tretmanu na $550^{\circ} \mathrm{C}$ u toku $3 \mathrm{~h}$. Osim pikova $\mathrm{FA}$, javljaju se i pikovi $\mathrm{CaCO}_{3} \mathrm{i}$
$\mathrm{CaF}_{2}$. Ovo je dokaz da iako se unutar micela površinski aktivne supstance delovi gradivnih blokova faza prekursora mogu lako transformisati u čisti fluorapatit, oni ipak ostaju nepromenjeni.

Naprotiv, smeša mlevena najmanje $2 \mathrm{~h}$ i dodatno termički tretirana $3 \mathrm{~h}$ potpuno je transformisana u čist fluorapatit. Slično je primećeno za uzorak mleven $8 \mathrm{~h}$. Pik koji odgovara FA samo se pomera ka većim uglovima difrakcije. To znači da je sadržaj OH-grupa smanjen tokom mlevenja uzorka i da je FA postao konačno prevladavajuća faza (pomešan verovatno sa malom količinom hidroksiapatita).

\section{MEHANIZAM REKACIJE}

Tokom mlevenja od pet minuta i $2 \mathrm{~h}$, reakcije u kojima nastaju $\beta$ - $\mathrm{Ca}_{2} \mathrm{P}_{2} \mathrm{O}_{7} \mathrm{i} \mathrm{CaF} \mathrm{Ca}_{2}$ su dominante, a deo $\mathrm{Ca}(\mathrm{OH})_{2}$ ostaje nepromenjen. Ovo ima snažan uticaj na brzinu sinteze FA, koja se odvija veoma sporo i ne može biti završena samo mlevenjem (čak i posle $8 \mathrm{~h}$ mlevenja). Ova niska brzina potiče od jako spore difuzije i preuređenja određenih jonskih vrsta, koje su neophodne za formiranje FA. Razmena i inkorporacija $\mathrm{Ca}^{2+}$ jona u prethodno formirane ćelije $\beta-\mathrm{Ca}_{2(1-\mathrm{x})} \mathrm{P}_{2(1-\mathrm{x})} \mathrm{O}_{7(1-\mathrm{x})} \mathrm{iCa}_{(1-\mathrm{x})} \mathrm{F}_{2(1-\mathrm{x})}$ snažno je inhibirana prisustvom EVA/EVV. Zbog toga, za veću brzinu reakcije formiranja FA, kristalna struktura $\beta-\mathrm{Ca}_{2(1-\mathrm{x})} \mathrm{P}_{2(1-\mathrm{x})} \mathrm{O}_{7(1-\mathrm{x})}$ $\mathrm{iCa} \mathrm{a}_{(1-\mathrm{x})} \mathrm{F}_{2(1-\mathrm{x})}$ mora biti prvo transformisana $\mathrm{u}$ amorfnu dodatnim mlevenjem (2-8 h). Ova procedura omogućava dobro mešanje, čime se umanjuju difuzioni putevi različitih jonskih vrsta.

Druga faza formiranja FA počela je nakon niskotemperaturnog tretmana uzoraka na $550^{\circ} \mathrm{C}$ tokom $3 \mathrm{~h}$. Tokom ovog koraka, prema nekim istraživanjima, reakcije mogu biti pokrenute na površini dominantne faze $\beta-\mathrm{Ca}_{2} \mathrm{P}_{2} \mathrm{O}_{7} \mathrm{kroz}$ površinsku difuziju dodatnih $\mathrm{Ca}^{2+}$ i F- jona u njenu zapreminu. Prema difrakcionim pikovima, evidentno je da je proces formiranja FA tokom tih termičkih tretmana veoma intenzivan. Jedini izuzetak bio je uzorak mleven pet minuta. Uprkos primenjenom termičkom tretmanu, tako kratko vreme mlevenja nije bilo dovoljno da se dobije monofazni sistem (FA). Međutim, mlevenje od najmanje $2 \mathrm{~h}$ dovelo je do formiranja čiste FA faze. Prisustvo gotovo zanemarljivog pika karakteristnog za $\beta-\mathrm{Ca}_{2} \mathrm{P}_{2} \mathrm{O}_{7}$ dokazuje da je ovo vreme mlevenja granično vreme za dobijanje mono faze FA.

Veoma je važno naglasiti da bez obzira na to koliko su uzorci mleveni, bez termičkog tretmana ne bi došlo do ove reakcije. Sa produženim vremenom mlevenja (do $3 \mathrm{~h}$ ili duže), sistem je postao amorfniji. Reakcija nije napredovala čak i tokom najdužeg vremena mlevenja $(8 \mathrm{~h})$, što je potvrđeno pomoću XRD. Napredak je primećen samo u amorfnijim uzorcima (mlevenim najmanje $2 \mathrm{~h}$ ) izloženim naknadnom termičkom tretmanu. Mehanizam procesa koji se dogodio tokom mlevenja verovatno je značajno aktiviran vodom prisutnom u $\mathrm{Ca}(\mathrm{OH})_{2}$. Objašnjenje Hedina i nekih drugih istraživača jeste to da manje čestice $\mathrm{Ca}(\mathrm{OH})_{2}$ tokom mlevenja pod dejstvom sila smicanja pokazuju tendenciju da rastu, izazivajući dalju dezintegraciju [29-31], pa razmena različitih jonskih vrsta postaje efikasnija.

Tokom mlevenja distorzija $\mathrm{Ca}^{2+}-\mathrm{O}$ poliedara je mnogo izraženija nego $\mathrm{P}^{5+}-\mathrm{O}$ tetraedara. Distorzija je dovela do pomeranja katjona od centra njegove koordinacione sfere. Ona ima jak uticaj na brzinu difuzije preostalih količina $\mathrm{Ca}^{2+} \mathrm{i} \mathrm{F}^{-}$jona i konsekventno razaranje $\beta-\mathrm{Ca}_{2} \mathrm{P}_{2} \mathrm{O}_{7}$ tokom mlevenja. Dakle, „prazan“ prostor u $\beta-\mathrm{Ca}_{2} \mathrm{P}_{2} \mathrm{O}_{7}$ ispunjen je sve više ovim jonskim vrstama, dok ćelija $\beta-\mathrm{Ca}_{2} \mathrm{P}_{2} \mathrm{O}_{7}$ ne bude potpuno razorena. 
Treba napomenuti to da je kapacitet rastvaranja $\mathrm{Ca}^{2+} \mathrm{i} \mathrm{F}^{-}$jona unutar $\beta-\mathrm{Ca}_{2} \mathrm{P}_{2} \mathrm{O}_{7}$ veoma visok. Shodno tome, manje veličine $\mathrm{CaF}_{2}$, a naročito $\mathrm{Ca}(\mathrm{OH})_{2}$ kristaliti, prikladni su za dalju propagaciju reakcije formiranja FA. Iako se kristalizacija amorfnih faza ne može postići kroz mlevenje, raspodela jona omogućava vrlo brzu kristalizaciju uzoraka u FA u sledećem koraku veoma slabog termičkog tretmana (na $550^{\circ} \mathrm{C}$ tokom $3 \mathrm{~h}$ ).

Stoga, čini se da unutar $\beta-\mathrm{Ca}_{2} \mathrm{P}_{2} \mathrm{O}_{7}$ strukture ima dovoljno prostora $\mathrm{za} \mathrm{F}^{-}$anjone da se postave u velike praznine, unutar mreže kalcijumovih i fosfatnih jona. Pored $\mathrm{F}^{-}$jona, veoma male nanočestice $\mathrm{CaF}_{2}$ smeštaju se nasumice u praznine $\mathrm{u} \beta-\mathrm{Ca}_{2} \mathrm{P}_{2} \mathrm{O}_{7}$ rešetki, koje proizvode značajne promene u njenoj simetriji, izazivajući odgovarajuće hemijske promene koje su odgovorne za transformaciju smeše $u$ fluorapatit tokom naredne termičke obrade. Ovaj tretman, kako je dokazano u ovim istraživanjima, može značajno ubrzati procese difuzije, uzrokujući degradaciju EVA/EVV micelarnih kaveza i podrške malim jonskim preraspodelama distorzijom $\mathrm{u}$ strukturi $\beta-\mathrm{Ca}_{2} \mathrm{P}_{2} \mathrm{O}_{7}$ izazvanoj silama smicanja, do konačne transformacije mešavine u fluorapatit.

\section{ZAKLJUČAK}

Mehanohemijski postupak sinteze fluorapatita bazira se na primeni dve vrste prekursora: kalcijum-hidroksida, fosforpentoksida i kalcijum-fluorida, odnosno kalcijum-hidroksida, fosfor-pentoksida i amonijum-fluorida uz dodatak površinski aktivne supstance vinil acetat/verstata. Na osnovu XRD i FTIR analize, kao mehanizma formiranja FA, uočeno je da fluorapatit ima značajne prednosti u poređenju sa hidroksiapatitom. Te prednosti su vezane za njegovu bolju stabilnost, nižu rastvorljivost i pre svega bolju zaštitu od karijesa.

\section{ZAHVALNOST}

Ovaj rad je podržan od strane Ministarstva prosvete, nauke i tehnološkog razvoja Republike Srbije (projekat br. 172026). 